\author{
MAŁGORZATA GŁOSKOWSKA-SOŁDATOW \\ Uniwersytet w Białymstoku
}

\title{
Sposoby motywowania uczniów do nauki stosowane przez rodziców i nauczycieli
}

\section{O motywacji}

Człowiek, wraz z przyjściem na świat staje się elementem otaczającej go rzeczywistości. Nieustannie przyswaja informacje, podejmuje różnorodne działania, przez co nabywa umiejętności i kształtuje osobowość. Każda jednostka, wykonując określone czynności prowadzące do osiagnięcia wyznaczonego uprzednio celu, powinna w jakiś sposób zagospodarować wkładaną weń energię. Owo zagospodarowanie dokonuje się za pośrednictwem mechanizmu regulacyjnego zwanego motywacja ${ }^{1}$.

Motywacja do nauki stanowi istotny element procesu edukacyjnego każdego człowieka. Jej poziom jest zdeterminowany wpływem wielu czynników tkwiących zarówno w samej jednostce jak i uwarunkowanych przez środowisko.

Jeżeli motywacja ma swoje źródła w wewnętrznych stanach podmiotu wtedy jest wewnętrzna, jeżeli w zewnętrznych stanach otoczenia - wtedy jest zewnętrzna. Motywacja może być również rozpatrywana z punktu widzenia jej dodatniego bądź ujemnego nacechowania, wówczas możemy mówić o motywacji pozytywnej bądź negatywnej. Motywacja pozytywna polega na stworzeniu perspektyw coraz lepszego urzeczywistniania własnych celów w miarę spełniania oczekiwań otoczenia, a motywacja negatywna opiera się na lęku, który pobudza do działania przez stwarzanie poczucia zagrożenia (np. publiczne ośmieszenie, zła ocena).

Przez motywację wewnętrzną rozumie się tendencję podmiotu do podejmowania i kontynuowania działania ze względu na sama treść tej aktywności ${ }^{2}$. Motywacja wewnętrzna pobudza do działania, które ma wartość samą w sobie; jej przykładem są indywidualne zainteresowania lub zamiłowanie do czegoś.

${ }^{1}$ J. Reykowski, Procesy emocjonalne, motywacja, osobowość, [w:] Psychologia, T. Tomaszewski (red.), Warszawa 1992.

${ }^{2}$ W. Łukaszewski, Motywacja w najważniejszych systemach teoretycznych, [w:] Strelau, J. (red.), Psychologia. Podręcznik akademicki, t. 2, Psychologia ogólna, Gdańsk 2000, s. 457. 
Motywacja wewnętrzna w odniesieniu do sytuacji szkolnej wiąże się z przyjemnością czerpaną z nauki, większą ciekawością świata, z niższym poziomem lęku przed szkołą, $\mathrm{z}$ tendencją do głębszego przetwarzania informacji, angażowania do tego lepszych strategii, wiąże się ze skłonnością do podejmowania zadań stanowiących wyzwanie dla człowieka, z lepszymi osiąnnięciami w nauce. Motywacja zewnętrzna stwarza zachętę do działania, które jest w jakiś sposób gratyfikowane, lub które pozwala na uniknięcie różnie rozumianej kary. Takiej motywacji sprzyja system ocen szkolnych, system nagród i kar, czy zbiór przepisów regulujących procedurę postępowania w określonej sytuacji. O motywacji zewnętrznej mówimy wówczas, gdy działanie jednostki realizowane jest ze względu na zewnętrzne wobec niego czynniki, majqce być konsekwencja jego wykonywania lub efektywnego zakończenia ${ }^{3}$.

Motywacja stanowi pewną celowość w działaniu jednostki, pobudza do podjęcia działań, dlatego związana jest nierozerwalnie z zagadnieniem działalności (pracy) człowieka. Zazwyczaj, gdy posiadamy wyższy poziom motywacji do czegoś, to jesteśmy bardziej skłonni podjąć się wykonania danej pracy, gdy zaś nie mamy motywacji, nic nie robimy. Mechanizm ten odnajduje zastosowanie we wszelkiej działalności ludzkiej, a szczególnie odnosi się do procesu edukacyjnego ${ }^{4}$.

Motywacja do nauki jest rozumiana jako tendencja ucznia do pojmowania czynności szkolnego uczenia się za sensowne i istotne oraz do szukania w nich zamierzonych pożytków. Motywacja ta jest uznawana za reakcję poznawczą, która zmierza do nadawania sensu czynności, przyswojenia wiedzy, jaką czynność niesie i opanowania umiejętności, do jakich sposobi ${ }^{5}$.

Według Brophiego motywacja uczniów do uczenia się ma dwa podstawowe znaczenia:

1. Jest ogólną dyspozycją, czyli postawą polegającą na uznawaniu uczenia się za coś wartościowego i wtedy uczeń rozpoczyna naukę z chęcią, zmobilizowany intelektualnie, z zamiarem przyswojenia wiedzy i umiejętności. Nauka jest traktowana naturalnie, a mechanizm motywacyjny występuje zawsze, gdy zachodzi potrzeba. Nawet kiedy praca ucznia nie jest przyjemna lub porywająca, to uczniowie odniosą się do niej poważnie tzn. uznają ją za sensowną i wartą poświęcenia czasu i wysiłku, ponieważ przyniesie im założone korzyści poznawcze.

2. Jest stanem występującym w określonej, specyficznej sytuacji. Wtedy stan motywacji do uczenia się polega na celowym i świadomym zaangażowaniu się w czynności przy jednoczesnej akceptacji celów działania i dążeniu do opanowania pojęć i umiejętności ${ }^{6}$.

\footnotetext{
${ }^{3}$ W. Łukaszewski., Motywacja w najważniejszych..., s. 457.

${ }^{4}$ T. Biernat, Motywacja do nauki szkolnej, „Wychowanie, na co dzień”, 1998, nr 12.

${ }^{5}$ J. Brophy, Motywowanie uczniów do nauki, Warszawa 2002.

${ }^{6}$ J. Brophy, Motywowanie uczniów do nauki, Warszawa 2002.
} 
Rozwijanie motywacji do nauki powinno być zadaniem ciąłym, systematycznym i koniecznym, gdyż jak powiedział Harrey Custing: (...) bez motywacji nie można zrobić nic wielkiego. Jest ona tym, co pcha człowiek do przodu? W uczeniu się szczególnego znaczenia nabiera motywacja poznawcza wpływająca na zainteresowania ucznia i dzięki temu przyczynia się chyba najbardziej do rozwoju umysłowej aktywności jednostki. Poprzez odpowiednie zabiegi dydaktyczne i wychowawcze motywację można rozwijać, stymulując uczniów do odpowiednio ukierunkowanych wysiłków. Oddziaływanie takie okazuje się szczególnie skuteczne, uczeń bowiem podejmuje wówczas określone wysiłki nie dlatego, że coś zostało mu narzucone, ale w następstwie tego, że odczuwa określone potrzeby i samodzielnie podejmuje działania, żeby je zaspokoić.

\section{O rodzicach}

Motywacja do nauki i osiągnięcia szkolne uczniów zależne są od wzajemnego układu i współdziałania bodźców płynących z oddziaływań środowiska rodzinnego i szkolnego. Zadaniem każdego rodzica i nauczyciela jest nie tylko pomóc dzieciom w ustaleniu celów, także wzbudzić w dzieciach wiarę w ich osiagnięcie.

Zatem rodzina i szkoła odpowiadają za budzenie, podtrzymywanie i utrwalanie pozytywnej motywacji do uczenia się, przejawiającej się w sumiennym i dokładnym wykonywaniu wszelkich obowiązków szkolnych. Odpowiednie nastawienie i pokierowanie procesem motywacyjnym dziecka zaowocuje jego pozytywnym nastawieniem do nauki szkolnej, rozwinięciem zainteresowań i w rezultacie może dokonać przekierowania orientacji ,nauki dla mamy i taty na nauke dla siebie ${ }^{8}$. Silnej motywacji w procesie edukacyjnym sprzyjają bliskie i pozytywne relacje z rodzicami, oparte na akceptacji, zrozumieniu potrzeb i uczuć dziecka, wsparciu, zainteresowaniu jego działaniem.

Rodzice powinni wiedzieć, co składa się na sukces edukacyjny, powinni sami być osobami, które odnoszą sukcesy, powinni dzielić z dziećmi realistyczne i pozytywne nastawienie do nauki. Zachowania i reakcje najbliższych osób mają wyraźny wpływ na motywację dzieci oraz ich stosunek do siebie i szkoły. Rodzice powinni się starać, aby dzieci chciały z nimi rozmawiać, żeby dobrze czuły się w domu i stawały się coraz bardziej samodzielne. Tylko wtedy można spodziewać się dobrych rezultatów w nauce i życiu.

Nie można przecenić wpływu, jaki wywiera dom rodzinny na stosunek ucznia do nauki. Motywację do uczenia się dziecka kształtują cechy charaktery-

\footnotetext{
${ }^{7}$ H. Custing, za: Walkiewicz M., Opis i analiza przypadku klasy z niska motywacja do nauki, „Nowa Szkoła” 2003, nr 1.

${ }^{8}$ T. Biernat, Motywacja do nauki szkolnej , „Wychowanie, na co dzień” 1998, nr 12.
} 
zujące rodziców i sytuacja domowa ucznia: wykształcenie i aspiracje rodziców, stosunek rodziców ucznia do szkoły oraz czas poświęcany dzieciom i ich sprawom szkolnym. Jeżeli rodzice wykazują pozytywną postawę wobec szkoły i nauki szkolnej oraz wysoko cenią wartość zdobywanej wiedzy, a także potrafią w domu stworzyć atmosferę sprzyjającą uczeniu się, wówczas uczeń ulega przekonaniu, że nauka szkolna jest jego najważniejszym obowiązkiem. W przeciwnym razie zainteresowanie ucznia nauką szkolną słabnie i sprowadza się do formalnego wypełniania obowiązku szkolnego.

Takim elementem o charakterze motywującym ucznia do nauki może być wykazanie przez rodzica zainteresowania jego sytuacją szkolną (nie tylko postępami w nauce, ale również pojawiającą się niechęcią i trudnościami). Ważną rzeczą jest ciagły kontakt rodzica $\mathrm{z}$ dzieckiem. Poprzez stworzenie właściwej atmosfery - opartej na zrozumieniu potrzeb dziecka (w tym także jego trudności), w której okazujemy zainteresowanie tym, co dziecko wykonuje, jak sobie radzi i zapewnieniu mu z naszej strony wsparcia - można zachęcić je do podejmowania każdego wysiłku, w tym także intelektualnego ${ }^{9}$. Każdy uczeń, niezależnie od wieku i szczebla nauczania pragnie, by otoczenie interesowało się jego osiagnięciami. Przeżywanie przez rodziców jego sukcesów i niepowodzeń, bycie z dzieckiem w czasie radości i podczas porażek, zachęca do uczenia się i zobowiązuje do większego wysiłku.

Postawy rodzicielskie, jakie reprezentują rodzice mają zatem wpływ na zachowanie dzieci, kształtowanie się więzi uczuciowej między członkami rodziny, a od niej zależy ogólna atmosfera rodzinna. Atmosfera panująca w rodzinie wywiera duży wpływ nie tylko na rozwój osobowości dziecka, stosunek do samego siebie i otaczającego świata ale także na jego postawy wobec przyswajanych treści ${ }^{10}$.

Motywowanie przez rodziców jest potężnym środkiem zmiany zachowania dzieci, jednak prawdziwa motywacja pochodzi z wnętrza dziecka, a nie z zewnętrznej presji rodziców. Rodzice powinni motywować dzieci chwaląc je. Pochwała to jeden ze skuteczniejszych czynników motywujących dostępny rodzicom. Kluczową sprawą w motywowaniu dzieci jest pozwolenie dziecku, aby wybrało to, co chce robić. Rodzice powinni wprowadzać dzieci w różne zajęcia, a następnie dokładnie przyglądać się ich reakcjom, zainteresowaniom i czekać, aż poproszą o możliwość zaangażowania się w coś. Dzieci mogą osiagać wielkie rzeczy, gdy w nie wierzymy.

Okazywanie dzieciom miłości polega po części na pomaganiu im w osiąganiu ich celów - nie w narzucaniu im naszych celów. Należy więc pomagać dzieciom wybrać własne cele i wyobrażać sobie pozytywne rezultaty osiagnięcia

\footnotetext{
${ }^{9}$ A. Faber, E. Mazlish, Jak mówić żeby dzieci się uczyty- w domu i w szkole, Poznań 2001.

${ }^{10} \mathrm{~J}$. Kawalec, Rola środowiska rodzinnego w wychowaniu dziecka sukcesu, „Edukacja i Dialog" 2000 , nr 5, s. 63.
} 
tych celów. Kiedy dzieci mają określone i sprecyzowane cele, stają się ogromnie umotywowane, by je osiągnąć. Wiedzą bowiem, że będą za to przed kimś odpowiadać. Poczucie odpowiedzialności przed kimś, połączone ze wsparciem, jest potężnym czynnikiem motywującym. Wsparcie rodziców wytwarza w dziecku energię, która popycha je do przodu, nawet jeśli wiele razy łatwiejsze wydaje się poddanie się. Niestety, u wielu rodziców widoczny jest brak rozumienia istoty motywowania dziecka. Z braku świadomości wychowawczej rodziców, z braku czasu oraz złej sytuacji materialnej rodzin dziecko może doznać krzywdy w tej delikatnej sferze, jaką jest motywacja.

\section{O nauczycielach}

Wśród elementów motywacji zewnętrznej i wewnetrznej na kształtowanie się stosunku uczniów do poszczególnych przedmiotów nauki olbrzymi wpływ ma nauczyciel wraz z całokształtem stosowanych przez siebie metod nauczania, systemem nagradzania, karania i oceniania oraz współpracy z domem rodzinnym wychowanka. Wpływ wychowawczy nauczyciela niekiedy bywa tak silny, że osoba nauczyciela staje się czynnikiem, który decyduje o postawie ucznia wobec szkoły, przedmiotu i o jego motywacji do uczenia się. Duży wpływ na uczniów i ich aktywność szkolną mają ci nauczyciele, którzy są przez dzieci lubiani i starają się ich zrozumieć.

Nauczyciel odgrywa podstawową rolę w kreowaniu postępów szkolnych dziecka, ponieważ od jego pracy zależy organizacja procesu uczenia się. Sprawna organizacja procesu uczenia się w młodszym wieku szkolnym rzutuje na rezultaty pracy szkolnej. Osobowość nauczyciela, jego upodobania, sposób przeprowadzania zajęć, stosunek do uczniów i do swojej pracy wywierają duży wpływ na stosunek uczniów do nauki. Sympatia dla nauczyciela jest silnym motywem uczenia się dzieci. Dlatego stosunki wzajemne między nauczycielem a dzieckiem mają bardzo duże znaczenie dla osiaggnięć w nauczaniu.

Uczniowie pierwszych lat szkolnych uczą się nie tyle dla zdobycia wiedzy ale przede wszystkim dla uznania i pochwały swego nauczyciela. Motywy uczenia się w pierwszych latach nauki mają charakter uczuciowy i są związane ze stosunkiem uczuciowym do nauczyciela. Kiedy stosunki między nauczycielem a uczniem są pozytywne, dziecko uczy się chętnie, gdy spotyka je ze strony nauczyciela niechęć lub niesprawiedliwość, stosunki pogarszają się, a w wyniku tego osłabiają się motywy uczenia się ${ }^{11}$.

Stosunek dziecka w pierwszej fazie młodszego wieku szkolnego jest pozytywny. Uczniów pociaga sam proces uczenia się, zaspokajanie wymagań nauczyciela a także praca $\mathrm{z}$ materiałem dydaktycznym. Dzieci lubią prace

\footnotetext{
${ }^{11}$ M. Tyszkowa, Czynniki determinujace prace szkolnq dziecka, Warszawa 1964.
} 
wymagająca jak największej aktywności: lubią czytać, pisać, liczyć, odpowiadać na pytania nauczyciela. W drugiej fazie wieku wczesnoszkolnego zjawiać się zaczyna zainteresowanie treścią przedmiotów szkolnych, niektórzy uczniowie mają nawet zainteresowanie określoną dziedziną wiedzy. W świadomości uczniów narasta przekonanie, iż nauka i uczenie się są środkiem do poznania rzeczywistości. Dziecko chce zostać dobrym uczniem, aby uzyskać pozycję w klasie, zaspokoić oczekiwania rodziców, ale bywa tak, że plany związane z przyszłą drogą życiową oraz poznawcze zainteresowania stają się motywami uczenia się uczniów w końcu tego okresu ${ }^{12}$.

Bodźcem aktywizującym do nauki nie może być ani nauczyciel zbyt rygorystyczny, zabijający w uczniu samodzielność, nierozwijający poczucia odpowiedzialności, ani też nauczyciel zbyt liberalny, hołdujący zasadzie „,wolnej ręki”. Ideałem nauczyciela jest nauczyciel demokrata, który pracuje ,z klasą”, a nie „obok klasy” na zasadzie wolności i prawa do krytyki oraz wyrażania swoich poglądów i przekonań. Osobowość nauczyciela może być zarówno bodźcem pozytywnym, jak i negatywnym. Cechy osobowości nauczyciela aprobowane przez uczniów, mają w procesie uczenia się wyraźny charakter motywacyjny i decydują bardziej o postawie uczniów, wynikach nauczania niż jego kwalifikacje zawodowe, program i metody nauczania ${ }^{13}$.

Według A. Tokarz stymulowanie motywacji do nauki jest ważnym zadaniem nauczyciela. Można sformułować kilka podstawowych zasad, wskazówek do stosowania na terenie szkoły:

1. konieczne jest w edukacji uwzględnianie potrzeb dziecka, ponieważ są one źródłem motywów,

2. zadania do wykonania dla ucznia powinny się odznaczać koniecznością przekroczenia dotychczasowych możliwości i kompetencji dziecka, powinny być wyzwaniem możliwym do realizacji,

3. zadania i działania charakteryzować powinna możliwość wyzwolenia ciekawości i fantazji, a tym samym pobudzenia do znacznego zaangażowania,

4. zadania uczniowskie powinny stać na wysokim poziomie w hierarchicznym systemie ważności,

5. nagrody (wzmocnienia) muszą się odznaczać adekwatnością do rodzaju motywacji (wewnętrznej lub zewnętrznej) oraz do siły motywacji, którą chcemy wywołać,

6. zadania powinny odnosić się do uznawanego, przyjętego systemu wartości i sprzyjać identyfikacji ze strukturą własnego ,ja"14.

Covington i Mannheim Teel podkreślaja, że stymulowanie do pozytywnej motywacji do nauki polega na zastosowaniu tzw. ,pięciu reguł równości”, po

${ }^{12}$ L. Wołoszynowa, Młodszy wiek szkolny, [w:] M. Żebrowska, Psychologia rozwojowa dzieci i młodzieży, Warszawa 1986, s. 577.

${ }^{13}$ L. Niebrzydowski, Wptyw motywacji na uczenie się, Warszawa 1972.

${ }^{14}$ A. Tokarz (red.), W poszukiwaniu zastosowań psychologii twórczości, Kraków 2005. 
spełnieniu których uczniowie czują się zmotywowani do osiagania najlepszych wyników bez negatywnej dynamiki i wyścigu umiejętności. Są to:

- zapewnienie równego dostępu do nagród - należy nagradzać obiektywnie według kryterium spełnienia standardów jakości wykonania pracy, a nie kryterium porównania efektów, wytworów, sposobów pracy do innych,

- nagradzanie osiągnięć i ciekawości - ocena powinna dotyczyć wytrwałości, jakości wysiłku i postępów,

- docenianie wielu różnych umiejętności - nagradzanie własnych pomysłów i refleksji, które są wyrażane wszelkimi innymi zdolnościami i umiejętnościami ucznia,

- oferowanie alternatywnych motywacji, czyli zastosowanie nagród, które odpowiadają potrzebom ucznia,

- proponowanie do wykonania zadań, które spowoduja zaangażowanie uczestników, czyli zadań, które stanowią dla ucznia nowość i zawierają element niespodzianki ${ }^{15}$.

\section{O sposobach motywowania}

Sposoby zmierzające do motywowania uczniów do nauki można podzielić ze względu na wykorzystywane czynniki na: zewnętrzne i wewnętrzne. Zewnętrzne czynniki motywujące w postaci nagrody, zapłaty, współzawodnictwa czy różnych form ograniczania, obniżają wewnętrzną motywację do aktywności. Dzieje się tak na skutek zmiany spostrzeganego umiejscowienia przyczyny działania (na zewnątrz, a nie wewnątrz podmiotu) oraz obniżenia związanego z tym poczucia sprawstwa, osobistego wpływu ${ }^{16}$. W sytuacji, gdy człowiek jest motywowany zewnętrznie, wybiera najłatwiejszą drogę, gdyż zwiększa to szansę uzyskania oczekiwanej nagrody zewnętrznej. Z kolei powtarzanie zdań podkreślających mocne strony, sprzyja uwierzeniu we własne możliwości i dzięki temu lepsze samopoczucie, które z kolei zwiększając naszą wiarę w możliwość kontrolowania sytuacji, daje chęci do dalszej nauki. Mniejszy nacisk na oceny zewnętrzne, włączenie elementów samooceny, sprzyja pojawieniu się motywacji wewnętrznej i związanych z nią konsekwencji ${ }^{17}$. Czynnikiem sprzyjającym pojawieniu się motywacji wewnętrznej mogą być również techniki uczenia się wzajemnego przez uczniów, przekazywania innym zdobytej wiedzy czy umiejętności. Techniki te wykorzystywane są często w aktywizującym podejściu do nauczania. Niestety, nauczyciele i rodzice zamiast koncentrować się na wzbudzaniu motywacji wewnętrznej na ogół wykorzystują zewnętrzne czynniki motywacyjne.

\footnotetext{
${ }^{15}$ M. V., Covington, Mannheim Teel K., Motywacja do nauki, Gdańsk, 2004.

${ }^{16}$ A. Tokarz, Rola motywacji poznawczej w aktywności twórczej, Wrocław 1985.

${ }^{17}$ E. L. Deci, Intrinsic motivation, Plenum Press, New York 1985.
} 
Nagroda odgrywa istotną rolę w uczeniu się, gdyż apeluje do pragnienia uzyskania aprobaty i uznania, a przez co wzmaga wysiłek, dodaje zapału i pobudza aktywność ucznia. Zwykle nagroda spełnia rolę mobilizującą do działania. Nagroda obiecana uczniowi przed przystąpieniem do zadania staje się bodźcem potęgującym jego wysiłek, a tym samym zapewnia lepsze wyniki. Natomiast nagroda udzielona po wykonaniu zadania jest potwierdzeniem odniesionego sukcesu. Udzielona rozsądnie i z umiarem taka gratyfikacja wywołuje u ucznia radość, zachwyt, uczucie powodzenia oraz spełnia trzy funkcje: jest wyrazem uznania dla ucznia za osiaggnięte wyniki, zaspokaja jego dążenie do znaczenia oraz wyzwala energię witalną i zachęca do wytrwałości. Nagroda jest czynnikiem pozytywnym, gdyż wiąże się z miłym dla ucznia przeżyciem, mobilizuje i zachęca do kontynuowania czynności wcześniej rozpoczętych. Należy ją jednak umiejętnie stosować, aby osiaggnać zamierzony cel.

Kara natomiast rozumiana jest jako przykry rezultat uczniowskiego postępowania i działania, ponieważ wiąże się z pojęciem strachu, bólu, wstydu, upokorzenia lub krzywdy. Jest jednym z negatywnych motywów stosowanych w procesie nauczania jako przymus i przybiera różne formy: zmniejszenia uprawnień dzieci zaniedbujących się w swoich obowiązkach szkolnych, zlecania dodatkowych prac lub ograniczenia czasu wolnego na zabawę, sporty i rozrywkę. Bodźce te są przejawem przemocy i nacisku w stosunku do uczniów, którzy nie mają wyrobionych nawyków odrabiania prac domowych, rozbudzonych głębszych zainteresowań poznawczych lub ambicji.

Kara jako motyw negatywny rzadko spełnia swoje zadanie. Mimo to wielu współczesnych pedagogów i psychologów uważa, że odwoływanie się w procesie nauczania i wychowania do kar jest konieczne. Zdaniem E. Hurlock kara jest potrzebna, gdyż pozwala poznać sposoby życia aprobowane $i$ potępiane przez grupe, a tym samym przyczynia się do utrwalenia reakcji powstrzymujacych od niewtaściwego zachowania się ${ }^{18}$.

Jeżeli nauczyciel lub rodzic karze i wynagradza w sposób właściwy, stosując indywidualizację i wczuwając się w sytuację dziecka, uczenie się będzie przebiegało prawidłowo, jeżeli będzie czynił to w sposób niewłaściwy osiagnie skutek przeciwny.

\section{O procedurze badawczej}

Celem badań było poznanie sposobów motywowania uczniów przez nauczycieli i rodziców oraz skonfrontowanie ich z rodzajem motywacji przejawianym przez uczniów

${ }^{18}$ E. Hurlock, Rozwój dziecka, Warszawa 1961, s. 459. 
Badania ankietowe w przeprowadzono wśród uczniów klas I-III oraz ich nauczycieli i rodziców. W badaniach wzięło udział 60 uczniów i ich rodziców oraz 30 nauczycieli kształcenia zintegrowanego (w tym nauczyciele uczący badane dzieci).Badania rozpoczęto od zebrania informacji dotyczących sposobów (metod, technik) motywowania uczniów do nauki. Chcąc porównać sposoby stosowane przez rodziców i przez nauczycieli wypracowano wspólne kategorie czynników, które wystąpiły w deklaracjach obu grup badawczych. W ten sposób wyodrębniono 9 kategorii czynników motywacyjnych. Podstawą przyporządkowania każdego z nich do określonej kategorii oraz sformułowania nazwy każdej z kategorii stał się rodzaj aktywności lub podejmowane działania osób motywujących (nauczyciela lub rodzica). Ustalono 9 kategorii jednakowych dla obu grup badawczych (rodziców i nauczycieli). Są to:

1. Stosowanie pozytywnych wzmocnień

2. Czynniki oparte na relacjach interpersonalnych

3. Czynniki oparte na karze i lęku

4. Posługiwanie się własnym przykładem

5. Organizacja pracy dziecka/ucznia

6. Zaangażowanie w sprawy dziecka/ucznia

7. Rozwijanie podstawowych kompetencji

8. Użyteczność zdobywanej wiedzy

9. Inne czynniki sprzyjające motywacji.

Następnym etapem postępowania badawczego było stworzenie narzędzia badawczego uwzględniającego różne sposoby działania i postępowania rodziców i nauczycieli sprzyjających motywowaniu dzieci/uczniów, w celu określanie ich wagi (w skali od 1 do 5) i tym samym umożliwiającego ich porównanie.

Z uwagi na specyfikę oddziaływań wychowawczych ustalono też kategorie czynników autonomicznych, niebędących wspólnymi dla rodziców i nauczycieli, występujących wyłącznie w domu rodzinnym (czynniki wskazujące na styl wychowania domu rodzinnego) i w szkole (związane z realizacją podstawowych założeń metodycznych nauczyciela).

Kategoria: style wychowawcze domu rodzinnego, jest rozumiana jako swoista synteza odpowiedzi dająca możliwość oceny stylu wychowania stosowanego w domu rodzinnym ucznia (demokratycznego, liberalnego i autokratycznego), wpływającego na atmosferę w domu.

Natomiast kategoria czynników związanych z realizacją podstawowych założeń metodycznych nauczyciela oznacza możliwość oceny oddziaływania na motywację ucznia następujących elementów: 
- wyraźnie określonych celów nauczania,

- dostosowania zadań do poziomu umiejętności uczniów (indywidualizacja),

- dobrego przygotowania nauczyciela do lekcji.

Spośród wspólnych dla obu środowisk kategorii pierwszą jest stosowanie pozytywnych wzmocnień. W środowisku nauczycieli i rodziców ocenie podlegały działania związane ze stosowaniem pochwał (stosowny zapis w dzienniczku, publiczna wyrażenie zadowolenia $\mathrm{z}$ dziecka), nagród (rzeczowe, pieniądze, słodycze), pozytywne oceny w stopniu lub przez symbole (,uśmiechnięte buźki”, słoneczka, „przybijanie piątki”), obietnice (pójście do kina, stanie w pierwszej parze, wspólne spędzanie czasu, np. przejażdżka rowerowa) i przypominanie, że niepowodzenia i błędy to normalny etap na drodze do doskonalenia się.

Kolejną kategorią jest grupa czynników opartych na relacjach interpersonalnych. Tu nauczyciele wskazywali przejawianie przyjaznego i opartego na zaufaniu stosunku do dziecka, gotowość do pomocy, serdeczne zwracanie się do dziecka, uśmiech, cierpliwość. Rodzice wskazywali okazywanie uczuć, budowanie przeświadczenia w dziecku, że bez względu na wszystko dziecko jest kochane przez rodziców, gotowość do rozmów, szczerość. doceniającej wysiłek ucznia. Obie grupy badane wskazywały dobry kontakt rodziców i nauczyciela jako interpersonalny czynnik pośrednio motywujący ucznia.

Trzecią wspólną kategorią są czynniki oparte na karze i lęku, czyli stosowanie kar. Nauczyciele przyznawali się do wpisywania uwag, stosowania oceny niedostatecznej bądź zapowiadania takiej możliwości, zadawanie dodatkowych prac dziecku, informowanie, że powiadomi się rodziców. Rodzice wymieniali jako karę zakaz korzystania z komputera czy telewizji, zakaz wyjścia na podwórko czy zabawy $\mathrm{z}$ rówieśnikami, spędzanie czasu $\mathrm{w}$ swoim pokoju, ostrzeżenia o konsekwencjach powtórzenia się określonej sytuacji bądź zdarzenia, ostrzeżenia przed możliwością odebrania przywilejów. Żadna z badanych osób nie przyznała się do stosowania kar cielesnych.

Kolejną kategorią czynników motywacyjnych stosowanych przez rodzica i nauczyciela jest posługiwanie się własnym przykładem. Nauczyciele wskazują: autorytet zawodowy, rzetelną własną pracę, utrzymywanie własnej motywacji do pracy na wysokim poziomie czy posługiwanie się własnym przykładem w określonych sytuacjach. Rodzice także posługują się własnym przykładem, wskazują wykształcenie własne jako czynnik motywacyjny do nauki czy ciekawą pracę, jako efekt dobrego uczenia się. Organizacja pracy dziecka jako grupa czynników motywujących do nauki w szkole przybiera postać właściwej organizacji zajęć, stosowania urozmaiconych metod nauczania, wykorzystywania możliwie często metod aktywizujących, właściwego wykorzy- 
stywania czasu, indywidualizowania pracy dziecka. Rodzice wymieniali przestrzeganie ustalonych godzin na odrabianie lekcji, określanie czasu spędzanego przed komputerem, zlecanie dzieciom obowiązków domowych, stworzenie właściwych warunków do nauki (np. wyłączenie komputera w czasie odrabiania lekcji), wymaganie punktualności, przestrzeganie godzin snu.

Szósta wspólna kategoria to zaangażowanie w sprawy dziecka. Nauczyciele - poprzez wspieranie ucznia w pracy i docenianie jego osiagnięć, uważne słuchanie dziecka, reagowanie na potrzeby uczniów, monitorowanie postępów ucznia w nauce. Rodzice - okazywanie zainteresowania nauką dziecka (np. rozmowy o szkole), przeżywać przez rodzinę zarówno sukcesów, jak i niepowodzenia, interesowanie się aktualnymi sprawami dziecka, uczestnictwo w życiu szkolnym (obecność na uroczystościach klasowych) znajomość rówieśników, z którymi dziecko spędza czas.

Kolejną kategorią jest rozwijanie podstawowych kompetencji. Tu podobnie wskazywali rodzice i nauczyciele: budzenie zainteresowań dziecka, rozwijanie czytelnictwa, zachęcanie do wykorzystywania komputera do spraw związanych z nauką, praca nad samodzielnością ucznia, uczenie systematyczności, budzenie inicjatywy i przedsiębiorczości. W szkole nauczyciele powinni wdrażać do wyciągania konstruktywnych wniosków z porażek oraz traktowanie wykonania niektórych zadań w kategoriach sukcesu dziecka. Rodzice podstawowe kompetencje mogą kształtować poprzez wyrabianie nawyku czytania książek w domu rodzinnym i wdrażanie dziecka do systematyczności w uczeniu się.

Następna wspólna kategoria to użyteczność zdobywanej wiedzy jako element motywujący dziecko. Nauczyciele ukazują korzyści płynące z uczenia się i wzbudzają zainteresowania danym przedmiotem, organizują sytuacje sprzyjające zastosowaniu wiedzy w sytuacjach praktycznych oraz wykorzystują wiedzę osobistą uczniów. Rodzice wymieniali jako motywujące do dalsze nauki możliwości wykorzystania wiedzy i umiejętności w pomocy rodzeństwu, korzystanie z wiedzy uczniów w różnych sytuacjach życiowych (przyk. znajomość słówek z języka angielskiego)

Ostatnią kategorią są inne czynniki sprzyjające motywacji. Niektóre wskazane przez rodziców i nauczycieli przykłady motywowania uczniów trudno było jednoznacznie zakwalifikować do wcześniej omówionych kategorii a ich rola motywacyjna może być kontrowersyjna. Znalazły tu się takie wskazania jak: współzawodnictwo i rywalizacja, podawanie przykładu innych dzieci czy rodzeństwa, siedzenie w ławce z lepszym od siebie uczniem. Pamiętając o zastrzeżeniach odnoszących się do takich sposobów oddziaływania na motywację zdecydowano o utworzeniu dodatkowej kategorii.

Szczegółowe wyniki badań oparte na wyłonionych kategoriach prezentuje poniższa tabela. 
Tabela 1. Ocena oddziaływania motywacyjnego kategorii czynników stosowanych przez rodziców i nauczycieli

\begin{tabular}{|c|l|c|c|}
\hline \multirow{2}{*}{ Kategorie czynników motywacyjnych } & Nauczyciele & Rodzice \\
\cline { 2 - 4 } & \multicolumn{2}{|c|}{ średnia } \\
\hline 1 & $\begin{array}{l}\text { związane z podstawowymi założeniami metodyczny- } \\
\text { mi* }\end{array}$ & 4,69 & $\mathrm{x}$ \\
\hline 2 & stosowanie pozytywnych wzmocnień & 4,38 & 3,54 \\
\hline 3 & czynniki oparte na relacjach interpersonalnych & 4,72 & 4,04 \\
\hline 4 & czynniki oparte na karze i lęku & 3,31 & 2,38 \\
\hline 5 & posługiwanie się własnym przykładem & 4,08 & 3,66 \\
\hline 6 & organizacja pracy dziecka & 4,46 & 3,61 \\
\hline 7 & zaangażowanie w sprawy dziecka & 4,67 & 4,00 \\
\hline 8 & rozwijanie podstawowych kompetencji & 3,94 & 3,70 \\
\hline 9 & użyteczność zdobywanej wiedzy & 3,84 & 3,71 \\
\hline 10 & inne czynniki sprzyjające motywacji & 4,32 & 3,64 \\
\hline 11 & style wychowania domu rodzinnego** & $\mathrm{x}$ & 3,03 \\
\hline
\end{tabular}

* kategoria czynników stosowanych wyłącznie przez nauczycieli

** oznacza kategorię czynników motywacyjnych stosowanych w domu rodzinnym ucznia

Analizie porównawczej podlegają wyłącznie kategorie wspólne (wiersze od 2 do $10 \mathrm{w}$ tabeli). Stwierdzić należy, iż nauczyciele przypisują generalnie większą moc motywacyjną wyróżnionym kategoriom czynników motywacyjnych, niż rodzice. Świadczyć to może o zdecydowanie większej świadomości nauczycieli, co do możliwości oddziaływania na tę sferę u uczniów. Z wyjątkiem 2 kategorii w wyższe średnie odnoszą się do wskazań nauczycieli. Najwyższe średnie ocen rodziców i nauczycieli dotyczą czynników opartych na relacjach interpersonalnych i zaangażowania $w$ sprawy dziecka. Cieszyć powinien fakt dostrzegania przez nauczycieli roli metodycznych rozwiązań służących motywowaniu uczniów do nauki. Obie kategorie czynników należy uznać za bardzo zbliżone - obie grupy badawcze dostrzegają w pierwszej kolejności konieczność zapewnienia dobrych relacji z dzieckiem i utrzymania własnego zaangażowania w sprawy dziecka.

Najniższe średnie zanotowano w obu grupach badanych w ocenie czynników opartych na karze i lęku - odpowiednio 2,38 i 3,31. Mimo to niepokój może budzić waga, jaką przypisują nauczyciele do stosowania do tej kategorii czynników - uwagi, nagany, zakazy, ostrzeżenia i inne formy kar jakie pojawiły się we wskazaniach nauczycieli, jeżeli nawet powodują mobilizację do pracy ucznia, to są jednak ewidentnym przejawem przymusu i uniemożliwiają kształtowanie motywacji wewnętrznej. 


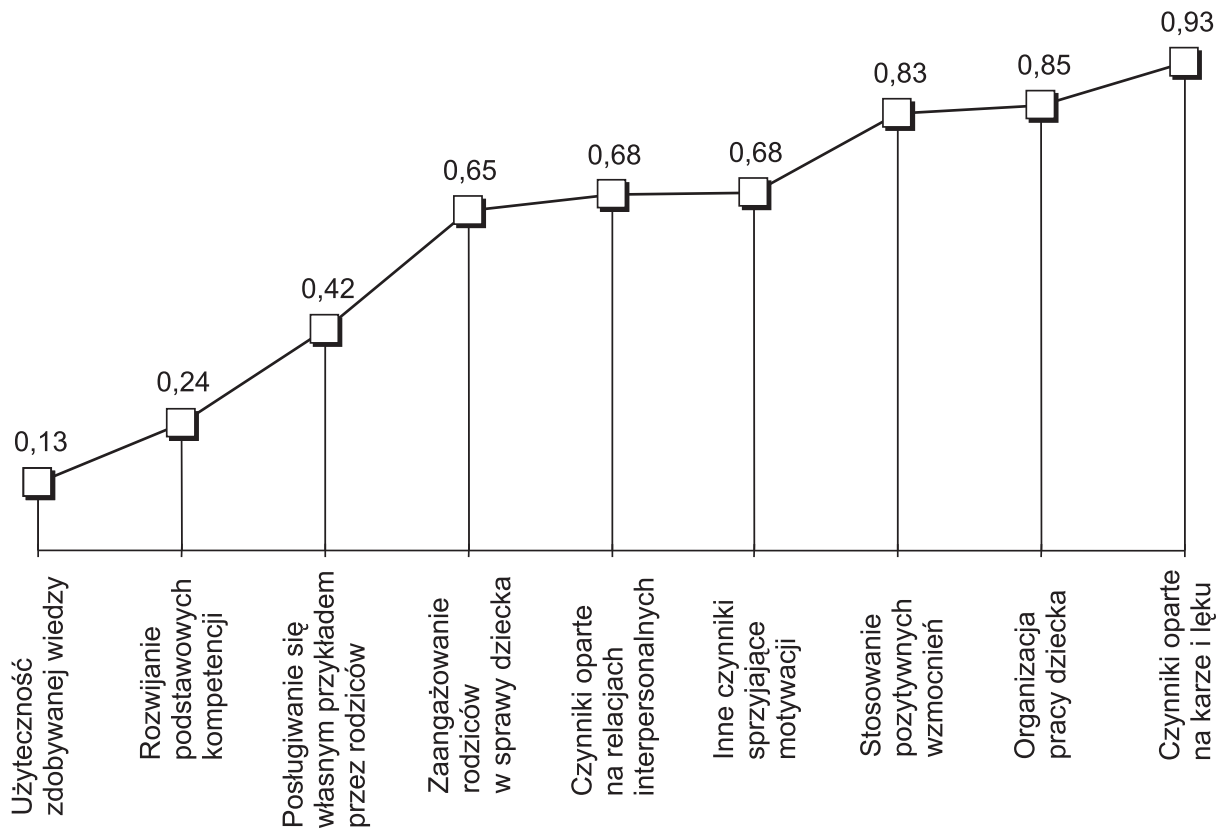

Wykres 1. Różnice w średnich ocenach kategorii między rodzicami a nauczycielami

Powyższy wykres ilustruje różnice między średnimi ocenami dotyczącymi poszczególnych kategorii motywowania ucznia do nauki. Najmniejsze różnice dotyczą oceny użyteczności zdobywanej wiedzy, a największe odnoszą się w przypadku kategorii czynników opartych na karze i lęku. Generalnie różnice w poziomie oceniania kategorii przez oba środowiska zamykają się w przedziale 0,80 średniej czyli $16 \%$ maksymalnej oceny.

Tabela 2. Oceny wszystkich czynników motywacyjnych

\begin{tabular}{|l|c|}
\hline \multicolumn{1}{|c|}{ Kategorie czynników } & Średnie \\
\hline Czynniki motywacyjne wskazywane i oceniane przez rodziców & 3,46 \\
\hline Czynniki motywacyjne wskazywane i oceniane przez nauczycieli & 4,31 \\
\hline Czynniki motywacyjne wskazywane i oceniane przez wszystkich respondentów & 3,85 \\
\hline
\end{tabular}

Opracowanie zestawienia najbardziej ogólnych ocen średnich wszystkich czynników motywacyjnych (nie kategorii czynników motywowania) pozwala jeszcze raz dostrzec wyraźną tendencję w wynikach badań. Znacznie wyżej oceniali rangę poszczególnych czynników motywacyjnych nauczyciele niż rodzice. 
Znając sposoby motywowania stosowane przez nauczycieli i rodziców oraz rangę, jaką przypisują poszczególnym kategoriom czynników motywacyjnych nauczyciele i rodzice, przystapiono do ostatniego etapu badań. Było to badanie rodzaju motywacji przejawianej przez dzieci, wobec których - można sadzić na podstawie deklaracji - stosowano wyżej omówione sposoby motywowania.

Przystępując do analizy danych warto przypomnieć, że kolejne typy regulacji zachowań, oparte na motywacji zewnętrznej, obejmują regulację zewnętrzną, oznaczającą brak internalizacji celów oraz regulację o różnym stopniu internalizacji celów: introjekcję, identyfikację i integrację ${ }^{19}$. Zewnętrznie regulowana aktywność bardzo ogranicza autonomię jednostki.

W przypadku introjekcji mamy do czynienia z przyjmowaniem regulacji zewnętrznych, przy braku pełnej na nie zgody. Przyjęte cele, normy, wartości jednostka akceptuje, ale nie utożsamia się z nimi i brak w niej pragnienia, aby pracować niezależnie.

Jeżeli chodzi o identyfikację, to ma ona miejsce kiedy jednostka rozpoznaje i przyjmuje wartości, oczekiwania, cele i normy, które są cenione przez otoczenie społeczne, co jest autentycznym źródłem zadowolenia i niekłamanej satysfakcji.

Natomiast integracja stanowi najbardziej pełną formę internalizacji. Przejawia się nie tylko identyfikacją z celami, ale też łączeniem ich z innymi komponentami własnego Ja.

Wymienione rodzaje motywacji stanowią kontinuum, które zaczyna się od braku poczucia wpływu na zdarzenia, a poprzestaje na pełnej autonomii.

Procesy regulacyjne typu: introjekcja, identyfikacja i integracja to trzy różne poziomy internalizacji prowadzacej od motywacji do motywacji wewnętrznej ${ }^{20}$.

$\mathrm{Z}$ analizy danych zilustrowanych na wykresie wynika, iż badani uczniowie w większości przejawiają motywację zewnętrzną do nauki, która charakteryzuje się tym, iż działanie podejmowane jest ze względu na zewnętrzne wymagania i oczekiwania. Regulacja zewnętrzna ma miejsce, gdy działanie jest sterowane poprzez nagrody zewnętrzne, presję lub ograniczenia, np. dziecko odrabia prace domową, ponieważ wie, że rodzic nagrodzi je za to.

Motywacja zewnętrzna typu introjekcja występuje u większej liczby dziewczynek niż chłopców. Można sadzić, że dziewczynki częściej podporządkowują się kontroli, normom bez pełnej wewnętrznej akceptacji i zgody, chłopcy z kolei dążą do niezależności w pracy.

W zakresie motywacji wewnętrznej typu identyfikacja, polegającej na tym, iż jednostka dostosowuje się do społecznie akceptowanych, cenionych norm,

${ }^{19}$ J. Uszyńska-Jarmoc, Od twórczości potencjalnej do autokreacji w szkole, Białystok 2007, s. 160 .

${ }^{20}$ Tamże, s. 160. 
zasad - występują zaledwie u 6\% ogółu badanych. Związane jest to z potrzebą uspołecznienia, afiliacji, kontaktu $\mathrm{z}$ innymi. Analizując dane możemy także zauważyć, że jedynie chłopcy przejawiają motywację wewnętrzną do nauki.

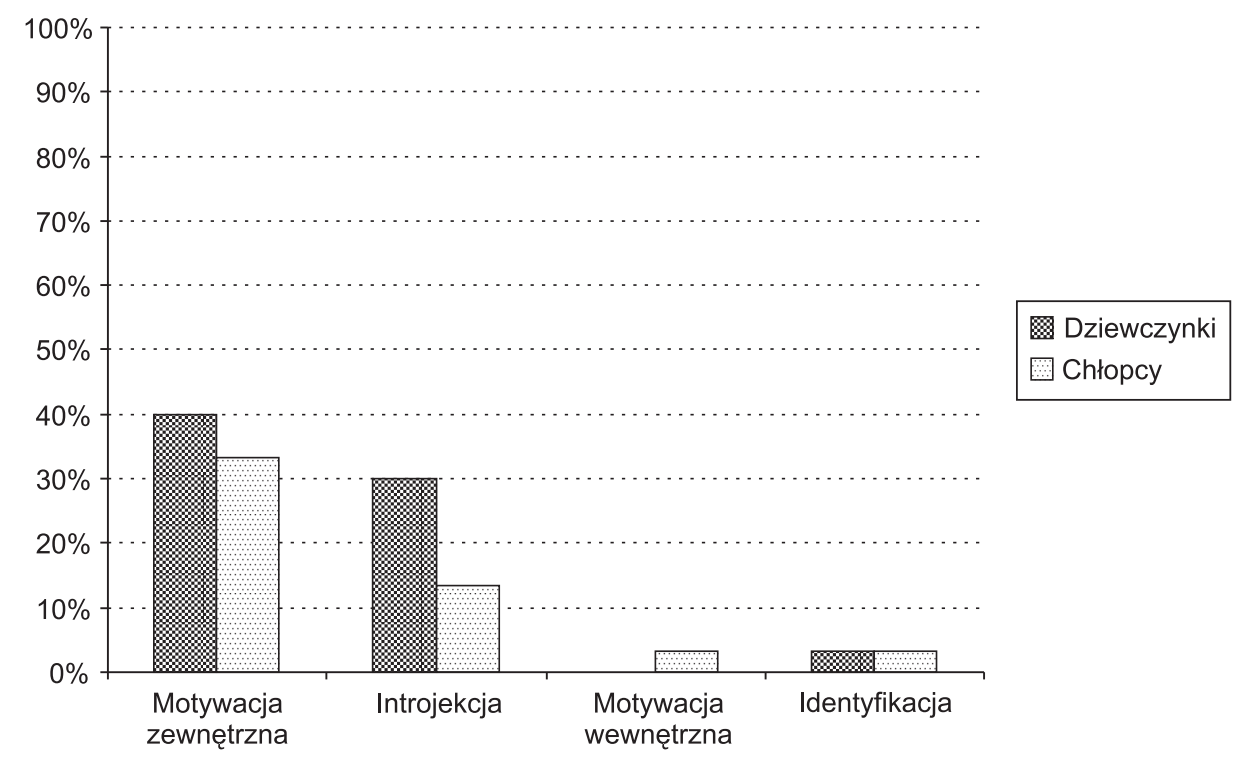

Wykres 2. Rodzaje motywacji

(Wyniki nie sumują się do 100\%, gdyż niektórzy respondenci w równym stopniu przejawiali co najmniej dwa rodzaje motywacji ).

Chociaż stanowią oni znikomy procent (ok.3\%), świadczy to o tym, iż ich działanie podejmowane jest wyłącznie ze względu na własną satysfakcję oraz zadowolenie. Przyczyny niskiego poziomu motywacji wewnętrznej tkwią zarówno w środowisku rodzinnym jak i szkolnym. Wśród czynników stosowanych przez nauczycieli i rodziców nieliczne odwołują się do uczucia satysfakcji z wykonanego działania, radości z samego działania czy stwarzanie dzieciom możliwości wyboru dającym im poczucie sprawstwa i wpływu na swoje działanie - a są to elementy składowe motywacji wewnętrznej.

Osiagniecie wyższego poziomu regulacji potęguje proces samoregulacji, a tym samym zwiększa prawdopodobieństwo wystąpienia działań motywowanych wewnętrznie. Uczniowie, którzy sami regulują swoje uczenie się, są bardziej aktywni: monitorują, kontrolują wiedzę, usprawniają swoją naukę poprzez stosowanie różnych strategii motywacyjnych. Należy, więc zachęcać uczniów do uczenia się samoregulowanego, ponieważ stwarza to wspaniałe warunki by wyzwolić w jednostce wewnętrzną motywację do nauki. Motywując uczniów do nauki należy pamiętać, żeby czynić ich od początku odpowiedzialnymi za swoją naukę 
MaŁgORZATA GŁosKowsKa-SOŁDATOW

\section{Motivating students to learn - methods used by parents and teachers}

This document is dedicated to the problem of motivation. It discusses the questions of ways of motivating the youngest pupils to the learning process. It presents the results of researches concerning motivational actions undertaken by teachers and parents, and compares them. The author presents the practical possibilities of applying motivation into the learning process. 